4 Macphee GJA, McInnes GT, Thomson GG, Brodie MJ. Verapamil potentiates carbamazepine neurotoxicity: a clinically important inhibitory interaction. Lancet 1986; $:$ :700-3.

5 Brodie MJ, Macphee GJA. Carbamazepine neurotoxicity precipitated by diltiazem. $\mathrm{Br}$ Med 7 1986;292:1170-1.

(Accepted 27 October 1987)

Clinical Pharmacology Unit, University Department of Medicine, Western Infirmary, Glasgow G11 6NT

JOHN G LARKIN, MB, MRCP, medical registrar

ELAINE BUTLER, medical technician

MARTIN J BRODIE, MD, FRCP, consultant clinical pharmacologist

Correspondence to: Dr Brodie.

\section{Plasma concentrations of atrial natriuretic peptide in hypothyroidism}

Atrial natriuretic peptide may play an important part in plasma volume homoeostasis in normal humans because of its ability to cause natriuresis, diuresis, and vasodilatation. Hypothyroidism is accompanied by abnormalities in both the cardiovascular system and water balance. ${ }^{123}$ Our study investigated the plasma concentrations of atrial natriuretic peptide in hypothyroidism.

\section{Patients, methods, and results}

We studied a group of 15 patients in whom clinical and biochemical hypothyroidism had been newly diagnosed (mean age 49, range 23-73) and group of 21 healthy normal subjects (mean age 43, range 27-86). In addition, 10 patients were restudied after treatment with thyroxine for six to 12 weeks. None had signs of heart failure, valvular heart disease, or hypertension (blood pressure $>150 / 90 \mathrm{~mm} \mathrm{Hg}$ ). Venous blood from the forearm was drawn between 0900 and 1100 after 30 minutes of quiet sitting and placed into cooled tubes containing sequestrene and aprotinin. On the same day the peptide was extracted from plasma with octadecyl silica and methanol. ${ }^{4}$ The mean recovery was $70 \%$, and the results are given uncorrected for the losses.

The concentration of atrial natriuretic peptide was measured with a previously described radioimmunoassay using a polyclonal antibody to the carboxy terminus of atrial natriuretic factor 99-126 (Peninsula Laboratories) and an iodine-125 label (Amersham). ${ }^{4}$ Intraassay and interassay variations were $10 \%$ and $12 \%$ respectively, and samples from before and after treatment were measured in the

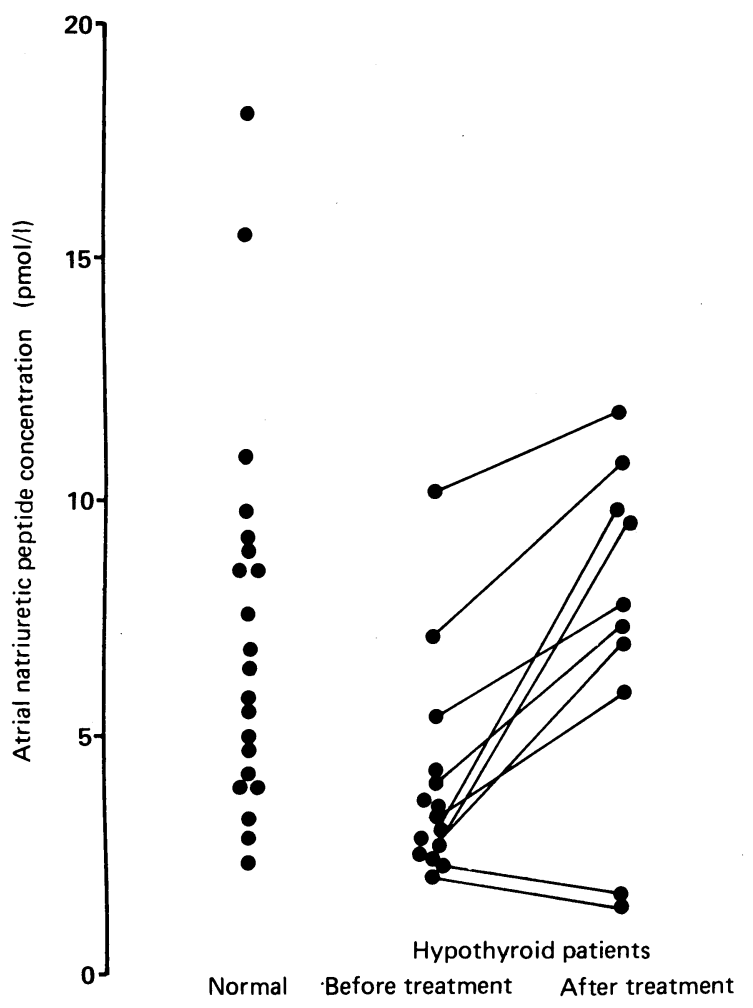

Plasma concentrations of atrial natriuretic peptide in normal subjects and hypothyroid patients before and after treatment. same assay. The concentration of plasma atrial natriuretic peptide increases in normal subjects who are receiving a high intake of sodium, so the 24 hour urinary sodium excretion was also measured on the day of the study. Diet was unrestricted. Because of the small numbers of subjects and the finding that plasma concentrations in each group showed a skew distribution the results are expressed as median and range, and the groups were compared with the Wilcoxon paired and unpaired tests.

The concentration of plasma atrial natriuretic peptide in the hypothyroid group (median $3.3 \mathrm{pmol} / \mathrm{l}$, range $2 \cdot 1-10.2 \mathrm{pmol} / \mathrm{l})$ was lower $(\mathrm{p}<0.01)$ than in the controls (median $6 \cdot 5 \mathrm{pmol} / 1$, range $2 \cdot 3-18 \cdot 1 \mathrm{pmol} / \mathrm{l}$ ) (figure). In 10 patients the median pretreatment value $(3 \cdot 0 \mathrm{pmol} / \mathrm{l}$, range $2 \cdot 1-10 \cdot 2 \mathrm{pmol} / \mathrm{l})$ increased significantly after treatment with thyroxine (median $7.6 \mathrm{pmol} / \mathrm{l}$, range 1.4 . $11.8 \mathrm{pmol} / 1 ; \mathrm{p}<0.01$ ). There was no significant difference between the 24 hour urinary sodium excretion of the control group (median $148 \mathrm{mmol}$, range $45-288 \mathrm{mmol}$ ) and the hypothyroid group (median $130 \mathrm{mmol}$, range $65-$ $191 \mathrm{mmol}$ ).

\section{Comment}

The decreased median concentration of atrial natriuretic peptide in hypothyroidism confirms the results of a smaller study in which urinary sodium excretion was not measured. ${ }^{5}$ By contrast, we have reported increased plasma concentrations of peptide in patients who have untreated hyperthyroidism, ${ }^{4}$ a disease associated with an increased plasma volume. ${ }^{1} \mathrm{~A}$ low plasma volume has been reported in myxoedema, ${ }^{1}$ and this may decrease secretion of the peptide. A lack of circulating atrial natriuretic peptide may partly explain the impaired ability to excrete a water load, which recovers after treatment, ${ }^{2}$ and the enhanced arterial pressor response to angiotensin $\mathrm{II}^{3}$ - both are features of hypothyroidism.

The study was supported by the North East Thames Regional Health Authority locally organised research scheme.

1 Gibson JG, Harris AW. Clinical studies of the blood volume. V. Hyperthyroidism and myxedema. 7 Clin Invest 1939;18:59-65.

2 Ladenson PW, Goldenheim PD, Ridgeway EC. Rapid pituitary and peripheral tissue responses to intravenous L-triiodothyronine in hypothyroidism. F Clin Endocrinol Metab 1983;56:1252-9.

3 Hauger-Klevene JH, Brown $\mathrm{H}$, Zavaleta J. Plasma renin activity in hyper- and hypothyroidism. f Clin Endocrinol 1972;34:625-9.

4 Woolf AS, Moult PJA. Plasma levels of atrial natriuretic peptide in hyperthyroidism. Clin Endocrinol 1987;27:721-5.

5 Zimmerman RS, Gharib H, Zimmerman D, Heublein D, Burnett JC. Atrial natriuretic peptide in hypothyroidism. F Clin Endocrinol Metab 1987;64:353-5.

(Accepted 22 October 1987)

Academic Unit of Endocrinology and Diabetes, Whittington Hospital, London N19 5NF

A S WOOLF, MRCP, clinical research fellow

P J A MOULT, MD, MRCP, consultant endocrinologist and senior lecturer

Correspondence to: Dr Moult.

\section{Rubber glove asthma}

Rubber gloves are well known to dermatologists as causes of allergic dermatitis, the chemical responsible usually being an antioxidant or an accelerator added to the latex in its production. ${ }^{12}$ So far as we are aware asthma provoked by vapour given off by rubber gloves has not been described, though rhinitis and anaphylaxis due to contact have.

\section{Case report and investigations}

A 36 year old male laboratory technician presented with a two year history of increasingly troublesome attacks of cough and wheeze. These tended to occur about one hour after starting work and lasted until evening. Two weeks before attending the clinic he had a prolonged and more severe attack which required treatment with prednisolone. For the past 10 years he had been performing serological investigations for hepatitis and, more recently, the acquired immune deficiency syndrome and he was required to wear gloves, which he changed frequently. He attributed his attacks to the starch with which the gloves were powdered. He recalled one attack after drinking red wine.

Over three weeks he recorded his peak flow rate four times daily. During a week at work it averaged about $530 \mathrm{~V} / \mathrm{min}$, whereas during two weeks on holiday it averaged about $570 \mathrm{l} / \mathrm{min}$. During work he used an aerosol bronchodilator 14 times; he did not need it when off work.

Formal challenge tests with talc (control) and glove starch produced no reaction. Two sets of outwardly identical gloves were obtained from the manufacturers (Surgikos Ltd), microtouch and general purpose. The latter was the type he used at work. Putting on and taking off the microtouch gloves again produced no reaction, but after 10 minutes of the same manoeuvre with the 
general purpose gloves his peak flow fell from $580 \mathrm{l} / \mathrm{min}$ to $350 \mathrm{l} / \mathrm{min}$ within 15 minutes, necessitating inhalation of a bronchodilator. This challenge test with suspected and control gloves was repeated, and again a pronounced fall in peak flow occurred only with the general purpose gloves.

A dozen each of the microtouch and general purpose gloves were enclosed in conical flasks. Pure filtered air was drawn over them at $0.5 \mathrm{l} / \mathrm{min}$ and passed through a tube of activated charcoal; this was desorbed with carbon disulphide and analysed by gas chromatography and mass spectrometry. The vapours from the two types of gloves were compared and included many chemicals in common. Nevertheless, one peak was observed in the vapour from the general purpose gloves which was not present in the microtouch glove vapour; this was identified as a bicyclic terpene, probably carene. Semiquantitative analysis by selected monitoring showed that it was given off from the gloves in concentration of about 10 parts per billion per glove.

\section{Comment}

The patient remained symptom free after changing the gloves he used at work to the microtouch type, and in view of his sensitivity to the vapour we thought that it was inadvisable to carry out formal challenge testing with pure carene.

Carene is a terpene produced naturally by plants and may protect them from boring insects. It is found particularly in pine resin and is one component of the distillate that made oil of turpentine such an important skin sensitiser, leading to its replacement by the petroleum derived turpentine substitute. ${ }^{4}$ Curiously, the solid residue after distillation of pine resin, rosin or colophony, is also an important skin and lung sensitiser.

Inquiries of the manufacturers of gloves showed that the general purpose ones were imported ready made from Malaysia and had been supplied to the patient's employer about three years previously. No pine resin or terpenes were added to the latex in manufacture and these substances were probably present in the raw latex. Chemically this is quite possible, as carene may be produced from two molecules of isoprene, and latex is a polymer of the same chemical (figure).

1 Estlander R, Jolanki R, Kanerva L. Dermatitis and urticaria from rubber and plastic gloves. Contact Dermatitis 1986;14:20-5.
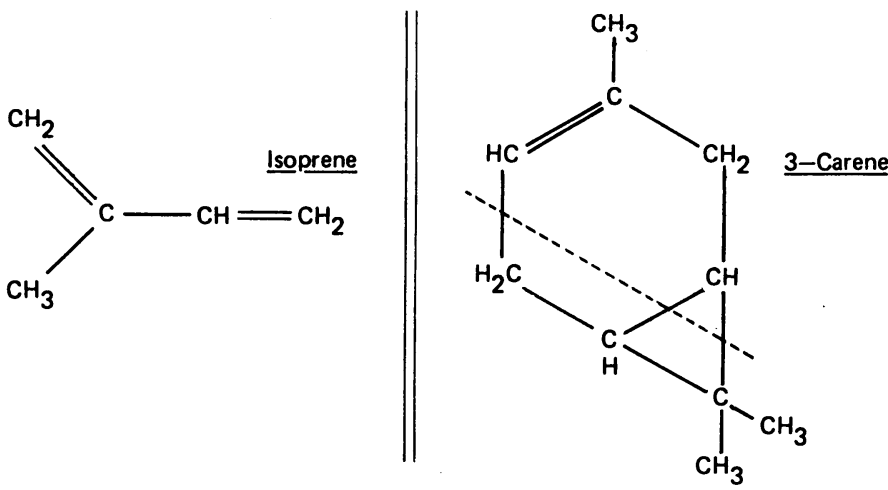

Natural latex is a polymer of isoprene. Bicyclic terpenes such as 3-carene are made up from two isoprene units as shown.

2 Nutter AF. Contact urticaria to rubber. Br $\mathcal{F}$ Dermatol 1979;101:597-8.

3 Carrillo T, Cuevas M, Munoz T, et al. Contact urticaria and rhinitis from latex surgical gloves. Contact Dermatitis 1986;15:69-72.

4 Cronin E. Oil of turpentine-a disappearing allergen. Contact Dermatitis 1979;5:308-11.

5 Burge PS, Perks WH, O'Brien M, et al. Occupational asthma in an electronics factory: a casecontrol study to evaluate aetiological factors. Thorax 1979;34:300-7.

(Accepted 15 October 1987)

Institute of Occupational Medicine, Edinburgh EH8 9SU

A SEATON, FRCP, FFOM, director

B CHERRIE, HNC, chemist

City Hospital, Edinburgh

JANE TURNBULL, MB, MRCP, senior house officer

Correspondence to: Dr Seaton.

\section{Meningitis complicating acute otitis media}

Meningitis is a potentially fatal complication of acute otitis media. We report on four adults who were admitted to this hospital during the past six months with meningitis secondary to acute otitis media. None of the patients had received antibiotic treatment before admission. In one case the disease was fatal.

\section{Case reports}

The table shows details of the patients. In two patients high resolution computed tomograms of the temporal bones showed defects in the roof of the tegmen and in one of these patients the scan also showed air in the middle cranial fossa. It was presumed that the air and bacteria from the acute otitis media had penetrated through the defect in the tegmen; this defect was closed with muscle and tissue glue.

\section{Comment}

Intracranial sepsis is a well recognised complication of chronic suppurative otitis media but is probably more common after acute otitis media. ${ }^{1}$ In one series acute otitis media was the source of infection in $30 \%$ of patients with pneumococcal meningitis. ${ }^{2}$ The routes of spread from the middle ear to the meninges are through defects in the tegmen, through emissary veins running from the mastoid to the dura, or through the labyrinth.

The role of antimicrobial treatment in children is controversial. Most clinicians treat acute otitis media with antibiotics, ${ }^{3}$ and the rate of suppurative complications after otitis media in childhood has decreased in the antibiotic era. ${ }^{4}$ In one trial, however, antibiotics were not shown to be superior to xylometazoline nosedrops and analgesics in childhood otitis media. In this particular study no complications of otitis media occurred. ${ }^{5}$ Acute otitis media in adults is fairly uncommon, and the four patients reported on here show that the complications can be severe. We therefore believe that adults should receive antimicrobial treatment as soon as acute otitis media is diagnosed. Failure to respond to antibiotics should be an indication for immediate referral for specialist treatment.

1 Brydoy B, Ellekjaer EF. Otogenic meningitis: a five year study. $\mathcal{F}$ Laryngol Otol 1972;86:871-80. 2 Keim RJ. Meningitis: the influence of routine otolaryngologic consultation on the morbidity and mortality in 290 cases. Laryngoscope 1978;88(suppl 9):1-28.

3 Bluestone CD. Otitis media in children: to treat or not to treat? N Engl f Med 1982;23:1399-403. 4 Sorenson H. Antibiotics in suppurative otitis media. Otolaryngol Clin North Am 1977;10:45-50.

5 Van Buchem FL, Dunk JHM, Van't Hof MA. Therapy of acute otitis media: myringotomy, antibiotics, or neither? Lancet $1981 ; \mathrm{ii}: 883-7$.

(Accepted 4 November 1987)

\section{Royal United Hospital, Coombe Park, Bath}

G J E M BATES, BSC, FRCS, senior registrar

A B DRAKE-LEE, FRCS, consultant

Correspondence to: Mr G J Bates, Coleman Laboratory, HSE 863, University of California, San Francisco, California 94143, USA.

Details of patients with acute otitis media and meningitis

\begin{tabular}{ccclcll}
\hline Case No & Sex & Age (years) & \multicolumn{1}{c}{ Symptoms } & Duration & Organism & Outcome \\
\hline 1 & F & 25 & Left otalgia, headache & 2 Days & Pneumococcus & Died \\
$2^{\star}$ & F & 37 & Left otalgia & 12 Hours & Streptococcus & Paralysis of left vocal cord and left hemiplegia \\
3 & F & 53 & Left otalgia, headache & 24 Hours & $\begin{array}{l}\text { Streptococcus } \\
\text { Full recovery }\end{array}$ & Fuld \\
4 & F & 64 & Right otalgia, right otorrhoea & 5 Days & Streptococcus & Full recovery
\end{tabular}

^This patient had had a similar episode when aged 25. The symptoms had lasted for two weeks and were due to haemophilus; she recovered fully. 